\section{Performance of Turkey Litter Compost as a Slow-release Fertilizer in Containerized Plant Production}

\author{
Helen T. Kraus \\ Virginia Cooperative Extension, Danville, VA 24540-2710 \\ Stuart L. Warren \\ Department of Horticultural Science, North Carolina State University, Raleigh, \\ NC 27695-7609
}

Additional index words. nitrogen, phosphorus, Rudbeckia fulgida 'Goldsturm', Cotoneaster dammeri 'Skogholm'

\begin{abstract}
An experiment was conducted to develop a protocol for using compost in nursery crop production. Five rates of inorganic fertilizer $(0,1,2,3$, and $4 \mathrm{~g} \mathrm{~N})$ and two irrigation volumes $(600$ and $900 \mathrm{~mL}$ per $3.8-\mathrm{L}$ container) were evaluated for their effects on Rudbeckia fulgida Ait. 'Goldsturm' and Cotoneaster dammeri Schneid. 'Skogholm' growth in a pine bark substrate amended with composted turkey litter (CTL). Additions of $\geq \mathbf{2} \mathrm{g}$ $\mathrm{N}$ per container for cotoneaster and $\geq 1.0 \mathrm{~g} N$ for rudbeckia were required to produce growth equivalent to that of plants in a control treatment that simulated typical production by a grower in the southeastern United States. Phosphorus, Ca, and Mg contents of cotoneaster and rudbeckia plants grown in CTL-amended substrates with no fertilizer added $(0 \mathrm{~g} \mathrm{~N})$ were similar to or greater than that of the control. Phosphorus concentrations in the substrate solutions were higher in all CTL-amended substrates than in the control regardless of fertilizer addition. This suggests that $P$ released from CTL had a greater impact than $P$ added with fertilizer. The greatest nutrient value of CTL may be as a $P$ source and a replacement for dolomitic limestone and micronutrients in containergrown plant production.
\end{abstract}

Composted turkey litter (CTL) is a viable amendment in production of containerized horticultural crops (Bilderback and Fonteno, 1991; Tyler et al., 1993a, 1993b). Amendment of pine bark with $8 \%$ (by volume) CTL increased container capacity and available water by $16 \%$ and $30 \%$, respectively, suggesting that compost-amended substrates might improve irrigation efficiency (Tyler et al., 1993a). Tyler et al. (1993b) reported that a pine bark substrate amended with $8 \%$ to $12 \%$ CTL produced plants (Cotoneaster dammeri 'Skogholm' and Hemerocallis sp. 'Red Magic') similar in size to those grown in pine bark amended with dolomitic limestone and micronutrients, and fertilized with $18 \mathrm{~g}$ Osmocote (17N-3P-10K). Chaney et al. (1980) and Falahi-Ardakani et al. (1987), using composted sewage sludge, reported similar results with various containerized crops, except that the compost did not release sufficient $\mathrm{N}$ to maximize growth. In a laboratory experiment, Kraus et al. (2000) reported that CTL had a $\mathrm{N}$ mineralization rate of $23 \mathrm{mg} /$ week at week one, and $\mathrm{N}$ at $4.5 \mathrm{mg} /$ week at the

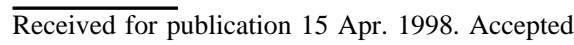
for publication 25 May 1999. The technical assistance of William Reece, Diane Mays, and the Analytical Service Laboratory, Dept. of Soil Science, is gratefully acknowledged, and the statistical guidance of William Swallow is greatly appreciated. The cost of publishing this paper was defrayed in part by the payment of page charges. Under postal regulations, this paper therefore must be hereby marked advertisement solely to indicate this fact.
\end{abstract}

end of a 16-week incubation. Results from this study suggested that CTL alone would not release adequate $\mathrm{N}$ to maximize growth in containerized plant production. In general, mature compost acts as a slow-release fertilizer regardless of the composted material or the substrate, partially or completely substituting for the traditional amendments of dolomitic limestone, micronutrients, and macronutrients. Bugbee and Frink (1989) stated, however, that most composts will not eliminate the need for supplemental fertilizer. Growers concerned with maximizing crop growth will not adapt the use of compost as an amendment in their substrate if they fear a reduction of growth. Therefore, we need a better understanding of production management of compost in container-grown plant production.

Amending container substrates with compost may require changes in irrigation and fertilization regimes. To develop a production protocol for containerized ornamental plant production that incorporates compost as an amendment to enhance physical properties and serve as a nutrient source, an experiment was conducted to evaluate five rates of inorganic fertilizer addition and two irrigation volumes on plant growth in a CTL-amended pine bark substrate.

\section{Materials and Methods}

The experimental design was a split-plot with five single-plant replications. Uniform seedlings of Rudbeckia fulgida 'Goldsturm' and rooted cuttings of Cotoneaster dammeri 'Skogholm' were potted into 3.8-L containers on 22 May 1995. The milled pine bark substrate was amended with $8 \%$ (by volume) composted turkey litter (CTL) (Sustane 5N0.9P-3.3K, Sustane Corp., Cannon Falls, Minn.) as this rate of CTL was reported to maximize air and water relations of pine bark substrates (Tyler et al., 1993a). Physical properties of this substrate are reported in Tyler et al. (1993a). Main plots received daily irrigations of 600 or $900 \mathrm{~mL}$ per container applied via pressure-compensated spray stakes (AcuSpray Stick, Wade Mfg. Co., Fresno, Calif.) at a rate of $200 \mathrm{~mL} \cdot \mathrm{min}^{-1}$. Irrigation was applied in two applications separated by a 2 -h interval. A daily irrigation of $900 \mathrm{~mL}$ was chosen as this volume has maximized growth of cotoneaster and rudbeckia in previous studies (Groves, 1995). Sub-plot containers received 0.0, 1.0, 2.0, 3.0, or 4.0 g N (Osmocote High N 24N1.7P-5.8K, The Scotts Co., Marysville, Ohio) applied as a topdressing. These additions also supplied $0.0,0.07,0.14,0.21$, and $0.28 \mathrm{~g} \mathrm{P}$ and $0.0,0.24,0.48,0.73$, and $0.97 \mathrm{~g} \mathrm{~K}$, respectively. No additional amendments were made to the compost-amended substrates, as CTL has been shown to adjust $\mathrm{pH}$ and supply $\mathrm{Ca}$, $\mathrm{Mg}$, and micronutrients needed for plant growth (Tyler et al., 1993a, 1993b). For comparison, an additional treatment consisting of an 8 pine bark : 1 sand (by volume) substrate amended with $3.0 \mathrm{~kg} \cdot \mathrm{m}^{-3}$ dolomitic limestone and 0.9 $\mathrm{kg} \cdot \mathrm{m}^{-3}$ Micromax (The Scotts Co.), topdressed with $3.5 \mathrm{~g} \mathrm{~N}(0.26 \mathrm{~g} \mathrm{P}$ and $0.85 \mathrm{~g} \mathrm{~K}$ ) (Osmocote High N), and irrigated with either 600 or 900 $\mathrm{mL}$ per container was included as a control. This treatment was added to simulate a container substrate and fertilizer rate used by a typical grower in the southeastern United States. Of the $24 \% \mathrm{~N}$ in Osmocote fertilizer, $6.6 \%$ was $\mathrm{NH}_{4}-\mathrm{N}, 5.9 \%$ was $\mathrm{NO}_{3}-\mathrm{N}$, and the remaining $11.5 \%$ was urea. Nitrogen, $\mathrm{P}$, and $\mathrm{K}$ sources included ammonium nitrate, ammonium phosphate, urea, calcium phosphate, and potassium sulfate.

Substrate solution was collected from containers of cotoneaster via the pour-through nutrient extraction method (Wright, 1986), at treatment initiation and every $21 \mathrm{~d}$ thereafter for $105 \mathrm{~d}$, and analyzed for $\mathrm{NO}_{3}-\mathrm{N}$ (Calaldo et al., 1975), $\mathrm{NH}_{4}-\mathrm{N}$ (Chaney and Marbach, 1962), and P (Murphy and Riley, 1962) using a spectrophotometer (Spectronic 1001 Plus; Milton Roy Co., Rochester, N.Y.). Solution $\mathrm{pH}$ was measured with an Accumet $\mathrm{pH}$ meter (Fisher Scientific Co., Fairlawn, N.J.). The solution sample was obtained by pouring 150 $\mathrm{mL}$ of distilled water on the substrate surface $2 \mathrm{~h}$ after irrigation and collecting the leachate. Irrigation water averaged $\left(\mathrm{mg} \cdot \mathrm{L}^{-1}\right): 0.05 \mathrm{NO}_{3}$ $\mathrm{N}, 0.34 \mathrm{NH}_{4}-\mathrm{N}, 0.2 \mathrm{P}$, and $0.4 \mathrm{~K}$ with a $\mathrm{pH}$ of 7.1 .

On 3 Oct. 1995, roots of cotoneaster only were placed over a screen and washed with a high-pressure water stream to remove substrate, tops of both species were removed, and all tissues were dried at $62{ }^{\circ} \mathrm{C}$ for $5 \mathrm{~d}$.

Data were subjected to analysis of variance procedures and regression analysis where appropriate (SAS Inc., 1985). Mean separations 
were performed via least significant difference (LSD) procedures at $P \leq 0.05$.

\section{Results and Discussion}

Irrigation volume and fertilizer additions affected plant growth and substrate nutrient solution concentrations; however, there were no significant irrigation volume $\times$ fertilizer interactions (data not presented). Shoot and root dry weights of cotoneaster and shoot dry weight of rudbeckia increased linearly as $\mathrm{N}$ rate increased from 0.0 to $4.0 \mathrm{~g} \mathrm{~N}$ (Table 1). CTL-amended substrates had to be supplemented with $\geq 2 \mathrm{~g} \mathrm{~N}$ per container to produce growth of cotoneaster equivalent to the control. Based on the $35 \%$ rate of mineralization reported by Kraus et al. (2000), a pine bark substrate amended with $8 \%$ CTL should release $3.62 \mathrm{~g} \mathrm{~N}$ over a 16 -week period. Even though this is similar to the quantity of $\mathrm{N}$ added to the control in this experiment, based on the results reported by Kraus et al. (2000) about half of the organic $\mathrm{N}$ would be mineralized in the first 4 weeks, resulting in a potential $\mathrm{N}$ deficiency later in the growing season.

In contrast, growth of rudbeckia in compost-amended substrate was greater than the control when topdressed with $\geq 1.0 \mathrm{~g} \mathrm{~N}$ (Table 1). Compost alone $(0 \mathrm{~g} \mathrm{~N})$ produced growth equivalent to the control. Differences in root morphology and rate of growth between cotoneaster and rudbeckia might explain the differing growth responses. Roots of rudbeckia were very fibrous and rapidly filled the container (personal observation). In contrast, roots

Table 1. Main effects of irrigation volume and rate of $\mathrm{N}$ application on shoot and root dry weights of cotoneaster and shoot dry weights of rudbeckia when grown in a pine bark substrate amended with $8 \%$ (by volume) composted turkey litter. Irrigation $\times \mathrm{N}$ applied interaction NS at $P>0.05$.

\begin{tabular}{|c|c|c|c|}
\hline \multirow[b]{3}{*}{ Treatment } & \multicolumn{3}{|c|}{ Dry wt $(\mathrm{g})$} \\
\hline & \multicolumn{2}{|c|}{ Cotoneaster } & \multirow{2}{*}{$\begin{array}{r}\text { Rudbeck } \\
\text { Shoot }\end{array}$} \\
\hline & Shoot & Root & \\
\hline Control ${ }^{\underline{z}}$ & 42.1 & 12.1 & 37.9 \\
\hline \multicolumn{4}{|c|}{ Irrigation $\left(\mathrm{mL} \cdot \mathrm{d}^{-1}\right)$} \\
\hline 900 & 40.0 & 10.0 & 53.9 \\
\hline 600 & 38.5 & 9.1 & 44.2 \\
\hline$P$ & NS & NS & 0.04 \\
\hline \multicolumn{4}{|c|}{$\underline{N}$ applied $(\mathrm{g})^{\mathrm{y}}$} \\
\hline 0 & $26.8^{*}$ & $7.8^{*}$ & 41.4 \\
\hline 1 & $35.3^{*}$ & $9.4^{*}$ & $45.2^{*}$ \\
\hline 2 & 42.0 & 10.5 & $47.4^{*}$ \\
\hline 3 & 43.6 & $9.5^{*}$ & $54.5^{*}$ \\
\hline 4 & $48.5^{*}$ & 10.5 & $56.8^{*}$ \\
\hline \multicolumn{4}{|l|}{ Regression $^{\mathrm{x}}$} \\
\hline $\mathrm{L}$ & 0.001 & 0.004 & 0.001 \\
\hline Q & NS & NS & NS \\
\hline
\end{tabular}

${ }^{2} 8$ pine bark : 1 sand $(\mathrm{v} / \mathrm{v})$ substrate amended with 3 $\mathrm{kg} \cdot \mathrm{m}^{-3}$ dolomitic limestone and $0.9 \mathrm{~kg} \cdot \mathrm{m}^{-3}$ Micromax, and topdressed with Osmocote High N ( $3.5 \mathrm{~g} \mathrm{~N}, 0.26$ $\mathrm{g} \mathrm{P}$, and $0.85 \mathrm{~g} \mathrm{~K}$ per container). Data not included in regression analysis.

${ }^{y}$ Nitrogen derived from topdressing with Osmocote High N (24N-1.7P-5.8K).

"Significantly different from the control based on mean separation by LSD at $P \leq 0.05$.

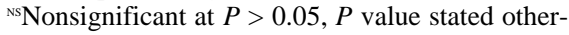
wise. of cotoneaster were less fibrous and did not fill the container for many weeks. Thus, $\mathrm{N}$ released from compost within weeks of potting may have been absorbed by roots of rudbeckia; whereas the early $\mathrm{N}$ released in containers of cotoneaster was lost to leaching.

Reducing the irrigation volume from 900 to $600 \mathrm{~mL}$ did not affect dry weight of cotoneaster (Table 1). Presumably, the increased container capacity and available water of the CTL-amended substrate (Tyler et al., 1993a) allowed for a reduction of $33 \%$ in irrigation volume without sacrificing plant growth. Shoot dry weight of rudbeckia, however, was reduced $18 \%$ when irrigated with $600 \mathrm{~mL}$ compared to $900 \mathrm{~mL}$. This difference in plant response may be related to the previously noted difference in root morphology, growth rate, and subsequent water usage.

Nutrient content of cotoneaster shoots was unaffected by irrigation volume, suggesting that nutrient absorption was similar regardless of irrigation volume (Table 2). Groves (1995) also reported that $\mathrm{N}$ content of Cotoneaster dammeri 'Skogholm' was unaffected by irrigation volume. The $\mathrm{N}, \mathrm{P}, \mathrm{K}, \mathrm{Ca}$, and $\mathrm{Mg}$ contents of cotoneaster shoots increased linearly with increasing rate of fertilizer addition
(Table 2). The shoot $\mathrm{N}$ content in the 0 and 1 $\mathrm{g} \mathrm{N}$ treatment was less than in the control, suggesting that $\mathrm{N}$ deficiency may have limited growth. This is further supported by a positive correlation $(P \leq 0.001, r=0.83)$ between shoot dry weight and N content. Similarly, shoot K content with no fertilizer $(0 \mathrm{~g} \mathrm{~N})$ was less than the control, suggesting a K deficiency. Tyler et al. (1993b) reported that CTL additions alone did not supply adequate $\mathrm{K}$. In contrast, $\mathrm{P}, \mathrm{Ca}$, and $\mathrm{Mg}$ contents of cotoneaster grown with no fertilizer additions $(0 \mathrm{~g} \mathrm{~N})$ were similar to those of the control (Table 2). This supports conclusions from prior studies that CTL can supply adequate quantities of $\mathrm{P}, \mathrm{Ca}$, and $\mathrm{Mg}$ for plant growth.

As for cotoneaster, nutrient contents of shoots of rudbeckia were unaffected by irrigation volume, whereas shoot $\mathrm{N}, \mathrm{P}, \mathrm{K}, \mathrm{Ca}$, and $\mathrm{Mg}$ contents increased linearly as rate of fertilizer addition increased from 0 to $4.0 \mathrm{~g} \mathrm{~N}$ (Table 2). Nutrient content and shoot dry weight of rudbeckia grown in CTL without supplemental $\mathrm{N}$ were as great or greater than those of the control. In addition, any supplemental fertilizer $(\geq 1 \mathrm{~g} \mathrm{~N})$ resulted in $\mathrm{N}, \mathrm{P}$, and Ca content greater than that of the control.

The $\mathrm{NH}_{4}-\mathrm{N}$ and $\mathrm{NO}_{3}-\mathrm{N}$ concentrations in

Table 2. Main effects of irrigation volume and rate of $\mathrm{N}$ application on nutrient content of shoots of cotoneaster and rudbeckia when grown in a pine bark substrate amended with $8 \%$ (by volume) composted turkey litter. Irrigation $\times \mathrm{N}$ applied interaction NS at $P>0.05$.

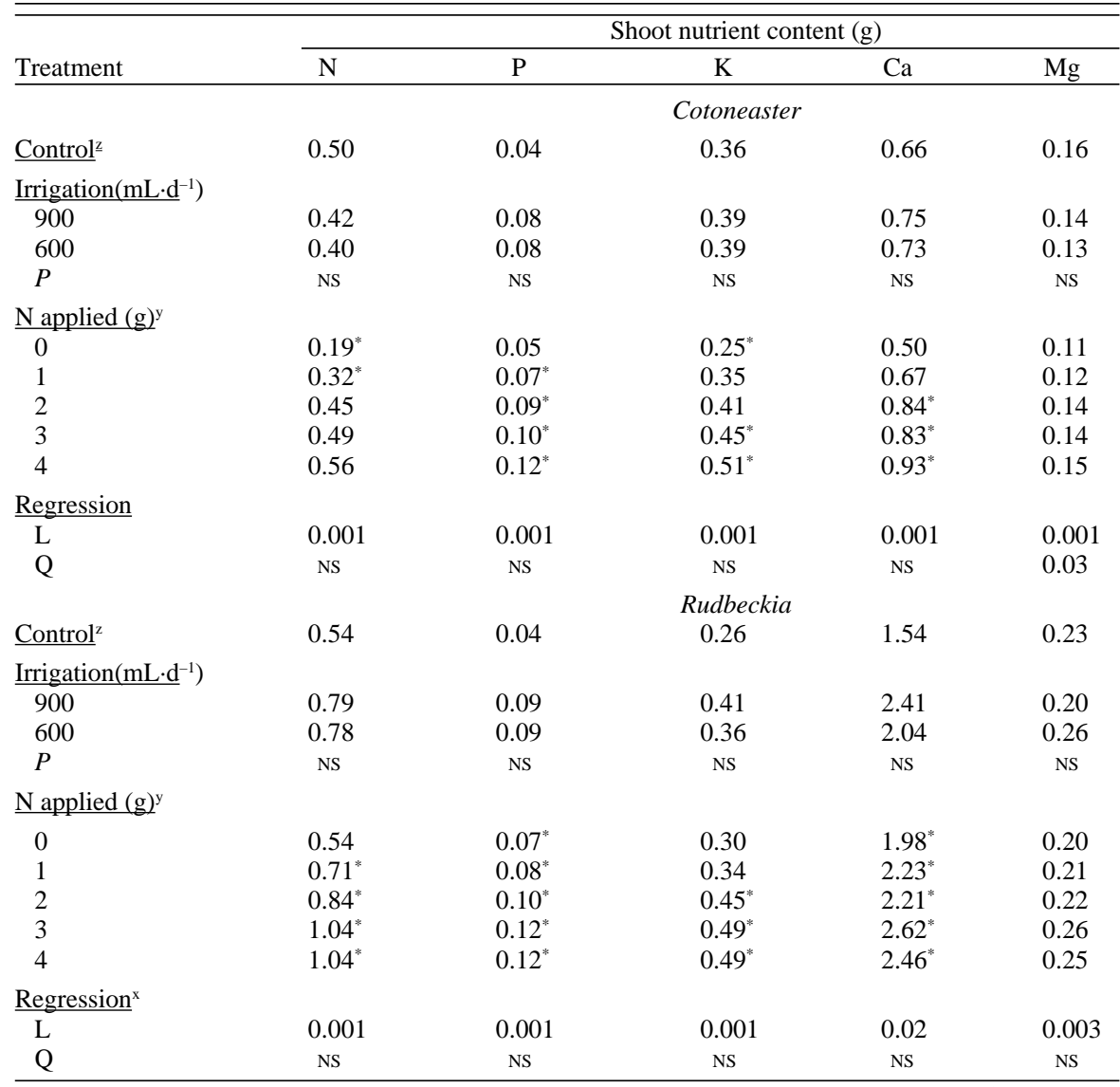

${ }^{\mathrm{z}} 8$ pine bark : 1 sand (v/v) substrate amended with $3 \mathrm{~kg} \cdot \mathrm{m}^{-3}$ dolomitic limestone and $0.9 \mathrm{~kg} \cdot \mathrm{m}^{-3} \mathrm{Micromax}$, and topdressed with Osmocote High N (3.5 g N, $0.26 \mathrm{~g} \mathrm{P}$ and $0.85 \mathrm{~g} \mathrm{~K}$ per container). Data not included in regression analysis.

${ }^{y}$ Nitrogen derived from topdressing with Osmocote High N (24N-1.7P-5.8K).

*Significantly different from the control based on mean separation by LSD at $P \leq 0.05$.

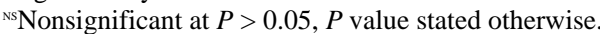


the substrate solution were similar throughout the study, except for $0 \mathrm{~d}$ after initiation (DAI); thus, only data for $\mathrm{NO}_{3}-\mathrm{N}$ are presented. The $\mathrm{NO}_{3}-\mathrm{N}$ concentration in the substrate solution was unaffected by irrigation volume except at 0 and $21 \mathrm{DAI}$, where $600 \mathrm{~mL}$ produced higher concentrations than $900 \mathrm{~mL}$ (Table 3). Substrate $\mathrm{P}$ was higher with the lower irrigation volume throughout the study. Regulation of leaching losses by adjusting irrigation volume has been reported by Tyler et al. (1996).

At 0 DAI, concentrations of $\mathrm{NH}_{4}-\mathrm{N}$ in the substrate solution were higher in all CTLamended substrates than in the control, indicating the rapid release of $\mathrm{NH}_{4}-\mathrm{N}$ from the compost (data not shown), as expected from the results reported by Kraus et al. (2000). Substrate $\mathrm{NO}_{3}-\mathrm{N}$ concentration increased linearly with increasing rates of $\mathrm{N}$ fertilizer through 63 DAI (Table 3). Additions of 3.0 and $4.0 \mathrm{~g} \mathrm{~N}$ increased $\mathrm{NO}_{3}-\mathrm{N}$ concentrations in the substrate solution relative to that in the control (3.5 $\mathrm{g} \mathrm{N})$ throughout the experiment, suggesting that CTL was contributing to the $\mathrm{NO}_{3}-\mathrm{N}$ concentration. Substrate $\mathrm{NO}_{3}-\mathrm{N}$ concentration of the CTL-amended substrate with $0 \mathrm{~g} \mathrm{~N}$ was not statistically different from that of the control throughout the study.

Phosphorus concentration in the CTLamended substrate solution was unaffected by rate of fertilizer addition (Table 3). All CTLamended substrates had greater $\mathrm{P}$ concentrations in the substrate solution than did the control. This suggests that $\mathrm{P}$ released from CTL had a greater impact than did $\mathrm{P}$ added with fertilizer, which supports studies by Tyler et al. (1993a, 1993b) and Williams and Nelson (1992). Thus, organic materials may play a prominent role in maintaining substrate $\mathrm{P}$ concentration for container production.

Substrate $\mathrm{pH}$ was unaffected by irrigation volume and fertilizer additions throughout the study, averaging 6.4 during the experiment (data not presented). In addition, there were no differences in $\mathrm{pH}$ between the control and the CTL-amended substrates. These data support previous studies indicating that CTL can replace dolomitic limestone when used in amending pine bark substrates (Tyler et al., 1993b).

In conclusion, to produce growth equivalent to the control, pine bark substrates amended with $8 \%$ CTL needed $\geq 2 \mathrm{~g} \mathrm{~N}$ per container for cotoneaster, whereas no additional fertilizer was needed for rudbeckia. The greatest nutrient value of CTL may be as a P source and a replacement for dolomitic limestone and micronutrients in container-grown plant production.

\section{Literature Cited}

Bilderback, T.E. and W.C. Fonteno. 1991. Use of horticultural rockwool, poultry litter compost and pine bark as container media. Proc. Southern Nurserymen's Assn. Res. Conf., 36th Annu. Rpt. p. 61-63.
Table 3. Main effects of irrigation volume (Irr.) and rate of $\mathrm{N}$ application ( $\mathrm{N}$ appl.) on $\mathrm{NO}_{3}-\mathrm{N}$ and $\mathrm{P}$ concentrations measured in leachate collected from containers of cotoneaster with a pine bark substrate amended with $8 \%$ (by volume) composted turkey litter at $0,21,42,63,84$, and $105 \mathrm{~d}$ after initiation (DAI). Irrigation $\times \mathrm{N}$ applied interaction nonsignificant at $P>0.05$.

\begin{tabular}{|c|c|c|c|c|c|c|}
\hline Treatment & 0 DAI & 21 DAI & 42 DAI & 63 DAI & 84 DAI & $105 \mathrm{DAI}$ \\
\hline \multicolumn{7}{|c|}{$\mathrm{NO}_{3}-\mathrm{N}\left(m g L^{-1}\right)$} \\
\hline Control $^{\underline{z}}$ & 9.2 & 7.3 & 3.5 & 1.3 & 1.3 & 1.1 \\
\hline \multicolumn{7}{|l|}{$\underline{\operatorname{Irr}}\left(\mathrm{mL} \cdot \mathrm{d}^{-1}\right)$} \\
\hline 900 & 8.9 & 7.9 & 3.9 & 1.9 & 0.3 & 2.0 \\
\hline 600 & 10.8 & 9.8 & 3.3 & 2.7 & 0.9 & 1.2 \\
\hline$P$ & 0.01 & 0.01 & NS & NS & NS & NS \\
\hline \multicolumn{7}{|l|}{$\mathrm{N}$ app. $(g)^{\mathrm{y}}$} \\
\hline 0 & 7.9 & 7.4 & 1.2 & 1.7 & 0.2 & 1.1 \\
\hline 1 & 9.1 & 7.0 & 1.9 & 2.1 & 0.2 & 1.0 \\
\hline 2 & 10.4 & 9.2 & 3.1 & 2.1 & 0.3 & 1.4 \\
\hline 3 & 11.1 & $11.8^{*}$ & $4.6^{*}$ & $3.3^{*}$ & 1.0 & 1.6 \\
\hline 4 & 11.0 & $10.5^{*}$ & $7.1^{*}$ & $3.6^{*}$ & 0.6 & 2.5 \\
\hline \multicolumn{7}{|l|}{ Regression $^{\underline{x}}$} \\
\hline $\mathrm{L}$ & 0.007 & 0.001 & 0.001 & 0.001 & NS & NS \\
\hline Q & NS & NS & NS & NS & NS & NS \\
\hline \multicolumn{7}{|c|}{$P\left(m g \cdot L^{-1}\right)$} \\
\hline$\underline{\text { Control }}^{\mathbf{z}}$ & 1.6 & 1.1 & 0.7 & 0.5 & 0.6 & 5.0 \\
\hline \multicolumn{7}{|l|}{$\underline{\operatorname{Irr}}\left(\mathrm{mL} \cdot \mathrm{d}^{-1}\right)$} \\
\hline 900 & 9.8 & 6.1 & 4.3 & 2.7 & 2.1 & 3.3 \\
\hline 600 & 11.6 & 7.9 & 6.4 & 4.0 & 3.4 & 3.5 \\
\hline$P$ & 0.05 & 0.05 & 0.05 & 0.05 & 0.05 & 0.05 \\
\hline \multicolumn{7}{|l|}{$\underline{\mathrm{N} \text { app. }(\mathrm{g})^{\mathrm{y}}}$} \\
\hline 0 & $14.0^{*}$ & $8.8^{*}$ & $6.1^{*}$ & $3.6^{*}$ & $3.1^{*}$ & $3.8^{*}$ \\
\hline 1 & $11.6^{*}$ & $8.2^{*}$ & $5.5^{*}$ & $3.7^{*}$ & $2.8^{*}$ & $4.0^{*}$ \\
\hline 2 & $12.3^{*}$ & $8.8^{*}$ & $6.3^{*}$ & $3.8^{*}$ & $3.0^{*}$ & $4.0^{*}$ \\
\hline 3 & $12.6^{*}$ & $7.3^{*}$ & $6.9^{*}$ & $4.4^{*}$ & $3.5^{*}$ & $4.0^{*}$ \\
\hline 4 & $12.1^{*}$ & $7.9^{*}$ & $6.7^{*}$ & $4.3^{*}$ & $3.6^{*}$ & $4.3^{*}$ \\
\hline \multicolumn{7}{|l|}{$\underline{\text { Regression }}$} \\
\hline $\mathrm{L}$ & NS & NS & NS & NS & NS & NS \\
\hline Q & NS & NS & NS & NS & NS & NS \\
\hline
\end{tabular}

${ }^{2} 8$ pine bark : 1 sand $(\mathrm{v} / \mathrm{v})$ substrate amended with $3 \mathrm{~kg} \cdot \mathrm{m}^{-3}$ dolomitic limestone and $0.9 \mathrm{~kg} \cdot \mathrm{m}^{-3}$ Micromax, and topdressed with Osmocote High N (3.5 g N, $0.26 \mathrm{~g} \mathrm{P}$, and $0.85 \mathrm{~g} \mathrm{~K}$ per container). Data not included in regression analysis.

${ }^{y}$ Nitrogen derived from topdressing with Osmocote High N (24N-1.7P-5.8K).

*Significantly different from the control based on mean separation by LSD at $P \leq 0.05$.

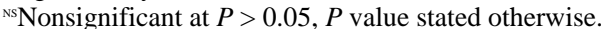

Bugbee, G.J. and C.R. Frink. 1989. Composted waste as a peat substitute in peat-lite media. HortScience 24:625-627.

Calaldo, D.A., M. Haroon, L.E. Schrader, and V.L. Youngs. 1975. Rapid colorimetric determination of nitrate in plant tissue. Commum. Soil Sci. Plant Anal. 6:71-80.

Chaney, A.L. and E.P. Marbach. 1962. Modified reagents for determination of urea and ammonia. Clin. Chem. 8:130-132.

Chaney, R.L., J.B. Munns, and H.M. Cathey. 1980 Effectiveness of digested sewage sludge compost in supplying nutrients for soilless potting media. J. Amer. Soc. Hort. Sci. 105:485-492.

Falahi-Ardakani, A., J.C. Bouwkamp, F.R. Gouin, and R.L. Chaney. 1987. Growth response and mineral uptake of vegetable transplants grown in a composted sewage sludge amended medium. I. Nutrient supplying power of the medium. J. Environ. Hort. 5:107-111.

Groves, K.M. 1995. Effect of irrigation volume, cyclic irrigation, and nutrient source on containerized plant production. MS Thesis. North Carolina State Univ., Raleigh.

Kraus, H.T., R.L. Mikkelsen, and S.L. Warren. 2000. Container substrate temperatures affect mineralization of composts. HortScience 35:1618.

Murphy, J. and J.P. Riley. 1962. A modified single solution method for the determination of phosphate in natural waters. Anal. Chim. Acta. 27:3136.

SAS Institute. 1985. SAS user's guide: Statistics. Ver. 5 ed. SAS Inst., Cary, N.C.

Tyler, H.H., S.L. Warren, and T.E. Bilderback. 1996. Reduced leaching fractions improve irrigation use efficiency and nutrient efficacy. J. Environ. Hort. 14:199-204.

Tyler, H.H., S.L. Warren, T.E. Bilderback, and W.C. Fonteno. 1993a. Composted turkey litter: I. Effect on physical and chemical properties of a pine bark substrate. J. Environ. Hort. 11:131136.

Tyler, H.H., S.L. Warren, T.E. Bilderback, and K.B. Perry. 1993b. Composted turkey litter: II. Effect on plant growth. J. Environ. Hort. 11:137-141.

Williams, K.A. and P.V. Nelson. 1992. Low, controlled nutrient availability provided by organic waste materials for chrysanthemum. J. Amer. Soc. Hort. Sci. 117:422-429.

Wright, R.D. 1986. The pour-through nutrient extraction procedure. HortScience 21:227-229. 